\title{
Editorial: Univentricular heart
}

\author{
Antonio F. Corno* \\ East Midlands Congenital Heart Centre, Glenfield Hospital, Leicester, UK
}

Keywords: bidirectional Glenn, congenital heart surgery, Fontan, palliation, univentricular heart

\section{Introduction}

Decades ago, the surgeons were asking themselves if it was possible to improve the natural history of patients with "functionally" univentricular heart (1). In order to facilitate the understanding and the subsequent decision making, for the first time, the patients with "functionally" univentricular heart were divided into two groups: (1) restricted pulmonary blood flow and (2) unrestricted pulmonary blood flow, with or without obstruction to the systemic blood flow (1).

Since the first stage in both groups is a palliative approach, over the years, the progress with the available materials and technology facilitated the surgical palliations to increase the pulmonary blood flow with systemic-to-pulmonary shunt (modified Blalock-Taussig shunt) $(2,3)$ as well as the control of distal pulmonary artery pressure and flow with adjustable pulmonary artery banding $(4,5)$.

The introduction of the use of the end-to-side anastomosis of the transected main pulmonary artery to the ascending aorta (Damus-Kaye-Stansel), as source of systemic blood flow, facilitated the management of patients with "functionally" univentricular heart with obstruction to the systemic blood flow (6).

The results of the surgical management have been substantially improved by the introduction of

OPEN ACCESS

Edited by:

Oswin Grollmuss,

Centre Chirurgical Marie

Lannelongue, France

Reviewed by:

Yasuhiro Fujii,

Okayama University Hospital, Japan Michael Huebler,

Kinderspital Zürich, Switzerland

${ }^{*}$ Correspondence:

Antonio F. Corno

tonycorno2@gmail.com

Specialty section:

This article was submitted to Pediatric Cardiology, a section of the journal

Frontiers in Pediatrics

Received: 27 July 2015

Accepted: 31 August 2015

Published: 14 September 2015

Citation:

Corno AF (2015) Editorial: Univentricular heart.

Front. Pediatr. 3:75.

doi: 10.3389/fped.2015.00075 the bidirectional Glenn (end-to-side anastomosis of the superior vena cava to the right pulmonary artery) as second stage between the first palliation to control the pulmonary blood flow and the final stage of dividing the systemic and the pulmonary venous returns (7).

The introduction of the extracardiac modified Fontan procedure as third surgical stage contributed to provide adequate early (8) and late (9) results, with better survival and lower incidence of complications.

The improved knowledge of the appropriate timing of indication and the adequate preparation for the third stage with Fontan circulation (10) together with progress in the intraoperative management (11) provided a further improvement in the surgical outcomes.

The availability of adequate research laboratories allowed the performance of sophisticated experimental studies on animals to improve the available knowledge on the mechanisms of chronic hypoxia $(12,13)$ and pulmonary hypertension $(14,15)$, characterizing respectively the two groups of patients, with "functionally" univentricular heart and restrictive or unrestrictive pulmonary blood flow.

Finally, the combination of experimental research with computational fluid dynamic studies prompted to evaluate the feasibility of the mechanical assistance for patients at high risk for modified Fontan procedure or with failure of the Fontan circulation (16).

\section{Recent Literature}

Several aspects of the management of patients with "functionally" univentricular heart have been investigated in the recent literature.

Considering the peculiar pathophysiology with difficult balance between systemic and pulmonary blood flow, often these patients require a period of stabilization before any surgical step, sometimes including resuscitation because of cardiac arrest or severe metabolic derangement (17). 
With regard to the ventricular morphology, several studies are still investigating the long-term ventricular function to evaluate if there is a difference in the performance between the right and left ventricular morphology (18).

Some brave surgeons, working in emergent economies, decided to proceed with a pulmonary artery banding as first palliative stage in patients with "functionally" univentricular heart at an average age much older than for the conventional management. Contrary to the expectations and the available knowledge, they have reported quite good results, with adequate long-term followup after the subsequent surgical steps (19).

Since the final goal of the multistage surgical procedures in patients with "functionally" univentricular heart is the Fontan circulation, one of the main factors allowing to reach the target is the adequate growth of the pulmonary arteries. Several studies have investigated the potential growth of the pulmonary arteries between the first palliation (either a modified Blalock-Taussig shunt or a pulmonary artery banding) and the bidirectional Glenn, and between the bidirectional Glenn and the modified Fontan procedure, using different criteria to evaluate the size of the pulmonary arteries: $Z$ score, McGoon ratio, and Nakata index. Disagreement still exists about the growth of the pulmonary arteries following interstage procedures (20).

The most challenging group of patients with "functionally" univentricular heart is the group with heterotaxy because of the frequently associated anomalies of the systemic and venous connections, the variable anatomy of the sinus node and conduction system, the common presence of atrioventricular valve regurgitation, and the difficulty in obtaining with surgical palliations an adequate balance between the systemic and the pulmonary blood flow (21).

With regard to the preservation of the ventricular function for the long-term performance of the unique ventricular chamber available, in association with the best possible choice of timing and type of the surgical procedures, attempts have been done at improving the ventricular function with medical treatments potentially unloading the single ventricle (22).

Thanks to the improved surgical results obtained in the last decades with relatively reduced mortality and morbidity, in the last few years, the attention of the caregivers has concentrated on the quality of life and the neurodevelopmental and cognitive development following the surgical procedures (23).

The goal in patients with "functionally" univentricular heart is always to possibly reach the stage of Fontan circulation, and the recent literature has recently reported articles on the importance of imaging in the perioperative assessment of Fontan patients (24), on the results of extracardiac Fontan procedure in adult patients

\section{References}

1. Corno AF, Becker AE, Bulterijs AHK, Lam J, Nijveld A, Schuller JL, et al. Univentricular heart: can we alter the natural history? Ann Thorac Surg (1982) 34:716-26. doi:10.1016/S0003-4975(10)60917-4

2. Corno AF, Hurni M, Payot M, von Segesser LK. Modified Blalock-Taussig shunt with compensatory properties. Ann Thorac Surg (1999) 67:269-70. doi:10.1016/ S0003-4975(98)01213-2

3. Corno AF, Hurni M, Tozzi P, von Segesser LK. Accordion-like prosthesis for modified Blalock-Taussig shunt. Asian Cardiovasc Thorac Ann (2003) 11:229-32. doi:10.1177/021849230301100311
(25), on the feasibility of establishing the Fontan circulation without cardiopulmonary bypass (26), on the post-operative respiratory function (27), on the not infrequent need for conversion of the previous Fontan procedure associated with arrhythmias surgery (28), and on the need of a multidisciplinary team of specialists for the long-term follow-up of the patients after Fontan type of surgery (29).

More importantly, the data collected in the North-American and European Congenital Data Base allow a very extensive documentation of the currently available information on indication, clinical practice, and outcomes in this challenging group of patients (30).

Despite the fact that in patients with "functionally" univentricular heart almost all surgeons are planning surgical steps toward the accomplishment of the Fontan circulation, few surgeons are still offering a ventricular septation in selected cases with double inlet left ventricle, with decent long-term outcomes (31).

Nevertheless, in a not negligible percentage of patients, because of the failure of the conventional surgery, heart transplant has to be considered in the presence of end-stage circulatory failure after Fontan procedure $(32,33)$.

\section{Research Topic}

Since there are still many unsolved questions and issues in the management of patients with "functionally" univentricular heart, this Research Topic has been organized to stimulate the people involved with these problems to provide their contribution to this timely and difficult matter.

The patients with "functionally" univentricular heart have been taken into consideration from the moment of pre-natal diagnosis (34) through detailed analysis of the complex and variable underlying morphology (35).

The decision-making process has been extensively investigated from the first surgical stage until the third stage (36), and particular efforts have been dedicated to the unsolved issues in the specific group of patients with hypoplastic left heart syndrome (37), including the potential contribution given by the computational fluid dynamic studies (38).

Finally, the long history of the surgical approaches used to separate the pulmonary from the systemic venous return obtaining the Fontan circulation has been reviewed, with precise analysis of the advantages and disadvantages of all the surgical techniques (39).

The extensive review and update performed in this Research Topic will be hopefully useful to all the readers involved with the treatment of this very difficult group of patients.

4. Corno AF, Bonnet D, Sekarski N, Sidi D, Vouhé P, von Segesser LK. Remote control of pulmonary blood flow: initial clinical experience. J Thorac Cardiovasc Surg (2003) 126:1775-80. doi:10.1016/j.jtcvs.2003.06.011

5. Corno AF, Prosi M, Fridez P, Zunino P, Quarteroni A, von Segesser LK. The non-circular shape of FloWatch ${ }^{\circledast}$-PAB prevents the need for pulmonary artery reconstruction after banding. Computational fluid dynamics and clinical correlations. Eur J Cardiothorac Surg (2006) 29:93-9. doi:10.1016/j.ejcts.2005. 10.029

6. Corno AF, Marino B, Catena G, Marcelletti C. Atrioventricular septal defects with severe left ventricular hypoplasia. Staged palliation. J Thorac Cardiovasc Surg (1988) 96:249-52. 
7. Mazzera E, Corno AF, Picardo S, di Donato R, Marino B, Costa D, et al. Bidirectional cavopulmonary shunts: clinical applications as staged or definitive palliation. Ann Thorac Surg (1989) 47:415-20. doi:10.1016/0003-4975(89) 90384-6

8. Marcelletti C, Corno AF, Giannico S, Marino B. Inferior vena cava to pulmonary artery extracardiac conduit: a new form of right heart bypass. J Thorac Cardiovasc Surg (1990) 100:228-32.

9. Giannico S, Corno AF, Marino B, Cicini MP, Gagliardi MG, Amodeo A, et al. Total extracardiac right heart bypass. Circulation (1992) 86(Suppl II):110-7.

10. Corno AF. Considerations on the cavopulmonary connection. Am Coll Cardiol Curr J Rev (1996) 5:38.

11. Corno AF, Horisberger J, Jegger D, von Segesser LK. Right atrial surgery with unsnared inferior vena cava. Eur J Cardiothorac Surg (2004) 26:219-20. doi:10. 1016/j.ejcts.2004.03.023

12. Corno AF, Milano G, Samaja M, Tozzi P, von Segesser LK. Chronic hypoxia: a model for cyanotic heart defects. J Thorac Cardiovasc Surg (2002) 124:105-12. doi:10.1067/mtc.2002.121302

13. Corno AF, Milano G, Morel S, Tozzi G, Genton CY, Samaja M, et al. Hypoxia: unique myocardial morphology? J Thorac Cardiovasc Surg (2004) 127:1301-8. doi:10.1016/j.jtcvs.2003.06.012

14. Corno AF, Tozzi P, Genton CY, von Segesser LK. Surgically induced unilateral pulmonary hypertension: time related analysis of a new experimental model. Eur J Cardiothorac Surg (2003) 23:513-7. doi:10.1016/S1010-7940(03)00025-3

15. Corno AF, Boone Y, Mallabiabarrena I, Augstburger M, von Segesser LK. Aqueous oxygen: the solution to relief hypoxic pulmonary hypertension. Eur J Cardiothorac Surg (2004) 26:301-5. doi:10.1016/j.ejcts.2004.03.050

16. Corno AF, Vergara C, Subramanian C, Johnson RA, Passerini T, Veneziani A, et al. Assisted Fontan procedure: animal and in vitro models and computational fluid dynamics study. Interact Cardiovasc Thorac Surg (2010) 10:679-84. doi: 10.1510/icvts.2009.223024

17. Marino BS, Tibby SM, Hoffman GM. Resuscitation of the patient with the functionally univentriculr heart. Curr Pediatr Rev (2013) 9:148-57. doi:10.2174/ 1573396311309020008

18. Backer CL. The functionally univentricular heart: which is better? Right or left ventricle? J Am Coll Cardiol (2012) 59:1186-7. doi:10.1016/j.jacc.2011.12.021

19. Sasikumar N, Ramanan S, Rema KM, Subramanyan R, Kumar RS, Cherian KM. Pulmonary artery banding for univentricular heart beyond the neonatal period. Asian Cardiovasc Thorac Ann (2013) 22:660-6. doi:10.1177/0218492313503640

20. Kansy A, Brzezinska-Rajszys G, Zubrzycka M, Mirkowicz-Malek M, Maruszewski P, Manowska M, et al. Pulmonary artery growth in univentricular physiology patients. Kardiol Pol (2013) 71:581-7. doi:10.5603/KP.2013.0121

21. Jacobs ML, Mavroudis C. Challenges of univentricular physiology in heterotaxy. World J Pediatr Congenit Heart Surg (2011) 2:258-63. doi:10.1177/ 2150135110396733

22. Yim DL, Jones BO, Alexander PM, d'Udekem Y, Cheung MM. Effect of antiheart failure therapy on diastolic function in children with single-ventricle circulations. Cardiol Young (2015) 5:1-7. doi:10.1017/S1047951114002376

23. Sarajuuri A, Jokinen E, Mildh L, Tujulin AM, Mattila I, Valanne L, et al. Neurodevelopmental burden at age 5 years in patients with univentricular heart. Pediatrics (2012) 130:e1636-46. doi:10.1542/peds.2012-0486

24. Navarro-Aguilar V, Flors L, Calvillo P, Merlos P, Buendia F, Igual B, et al. Fontan procedure: imaging of normal post-surgical anatomy and the spectrum of cardiac and extracardiac complications. Clin Radiol (2015) 70:295-303. doi: 10.1016/j.crad.2014.10.005

25. Ly M, Roubertie F, Kasdi R, Chatti S, Vergnat M, Luu D, et al. The modified Fontan procedure with use of extracardiac conduit in adults: analysis of 32 consecutive patients. Ann Thorac Surg (2014) 98:2181-6. doi:10.1016/j. athoracsur.2014.07.043

26. Talwar S, Muthukkumaran S, Choudhary SK, Makhija N, Sreenivas V, Saxena A, et al. A complete extracorporeal circulation-free approach to patients with functionally univentricular hearts provides superior early outcomes. World J Pediatr Congenit Heart Surg (2014) 5:54-9. doi:10.1177/2150135113507091

27. Idorn L, Jensen AS, Juul K, Reimers JI, Nielsen KG, Sondergaard L. New insights into the aspects of pulmonary diffusing capacity in Fontan patients. Cardiol Young (2014) 24:311-20. doi:10.1017/S1047951113000358

28. Backer CL. $12^{\text {th }}$ annual C. Walton Lillehei memorial lecture in cardiovascular surgery: Fontan conversion. The Chicago experience. Cardiol Young (2011) 21(Suppl2):169-76. doi:10.1017/S1047951111001764

29. Goldberg DJ, Dodds K, Rychik J. New concepts: development of a survivorship programme for patients with a functionally univentricular heart. Cardiol Young (2011) 21(Suppl2):77-9. doi:10.1017/S1047951111001636

30. Jacobs JP, Maruszewski B. Functionally univentricular heart and the Fontan operation: lessons learned about patterns of practice and outcomes from the congenital heart surgery databases of the European association for cardiothoracic surgery and the society of thoracic surgeons. World J Pediatr Congenit Heart Surg (2013) 4:349-55. doi:10.1177/2150135113494228

31. Kurosawa H, Arai T, Imai Y, Matsumura G. Ventricular septation for double inlet left ventricle. World J Pediatr Congenit Heart Surg (2012) 3:337-43. doi:10. $1177 / 2150135112443970$

32. Auerbach SR, Smith JK, Gralla J, Mitchell MB, Campbell DN, Jaggers J, et al. Graft survival is better without prior surgery in cardiac transplantation for functionally univentricular hearts. J Heart Lung Transplant (2012) 31:987-95. doi:10.1016/j.healun.2012.05.013

33. Rossano JW, Shaddy RE. Heart transplant after the Fontan operation. Cardiol Young (2013) 23:841-6. doi:10.1017/S1047951113001662

34. Corno AF. "Functionally" univentricular hearts: impact of pre-natal diagnosis. Front Pediatr (2015) 3:15. doi:10.3389/fped.2015.00015

35. Frescura C, Thiene G. The new concept of univentricular heart. Front Pediatr (2015) 2:62. doi:10.3389/fped.2014.00062

36. Davies RR, Pizarro C. Decision-making for surgery in the management of patients with univentricular heart. Front Pediatr (2015) 3:61. doi:10.3389/fped. 2015.00061

37. Arnold RR, Loukanov T, Gorenflo M. Hypoplastic left heart syndrome unresolved issues. Front Pediatr (2014) 2:125. doi:10.3389/fped.2014.00125

38. Biglino G, Giardini A, Hsia T-Y, Frigiola A, Taylor AM, Schievano S, et al. Modeling single ventricle physiology: review of engineering tools to study first stage palliation of hypoplastic left heart syndrome. Front Pediatr (2013) 1:31. doi:10.3389/fped.2013.00031

39. Kreutzer C, Kreutzer J, Kreutzer GO. Reflections on five decades of the Fontan Kreutzer procedure. Front Pediatr (2013) 1:45. doi:10.3389/fped.2013.00045

Conflict of Interest Statement: The author declares that the research was conducted in the absence of any commercial or financial relationships that could be construed as a potential conflict of interest.

Copyright (C) 2015 Corno. This is an open-access article distributed under the terms of the Creative Commons Attribution License (CC BY). The use, distribution or reproduction in other forums is permitted, provided the original author(s) or licensor are credited and that the original publication in this journal is cited, in accordance with accepted academic practice. No use, distribution or reproduction is permitted which does not comply with these terms. 